\title{
Government Pension Policy and the Cost of Labor and Capital
}

\author{
GREG NIEHAUS \\ University of Michigan, Graduate School of Business Adminstration \\ Ann Arbor, Michigan 48109 U.S.A.
}

\section{Abstract}

This article examines how the pension insurance provided by the PBGC and the tax treatment of pension plans affect the cost of labor and capital. Two important aspects of the insurance program are (1) the premium schedule and (2) an employer's liability for unfunded pension benefits (the deductible). These two aspects interact to increase the cost of capital relative to labor, especially for firms with underfunded plans.

\section{Introduction}

This article analyzes the distortions on a firm's choice of labor and capital induced by the mandatory pension insurance program operated by the Pension Benefit Guarantee Corporation (PBGC) and the preferential tax treatment of pension plans. Black (1980), Tepper (1981), and Sharpe (1976) study how the insurance and tax arrangements affect the financial management of pension plans, holding a firm's production decisions fixed. In contrast, this article studies a firm's production decisions (choice of labor and capital), treating its financial pension policies as exogenous. ${ }^{1}$ Thus, the focus is on the distortion of the real decisions of a firm caused by the government's pension policy.

Under the PBGC insurance program, a firm's liability for unfunded pension benefits (the insurance contract's deductible) depends on the financial condition of the firm. For example, if the firm has zero net worth, then the deductible is zero and the PBGC must cover the entire unfunded liability. Thus, increases in a firm's cash flows decrease the risk facing the PBGC. The PBGC, however, does not charge premiums that vary with the firm's cash flows. Consequently, shareholders pay all of the costs of projects which increase the firm's cash flows, but they share the returns with the PBGC. Thus, the combination of the PBGC's fee schedule and the sponsor's liability increases the required return on capital. The magnitude of this effect varies cross-sectionally depending on the funding status of the pension plan. For overfunded plans, the effect is inconsequential; however, for underfunded plans, the effect can be significant.

Sharpe (1976) illustrates the moral hazard problems associated with the PBGC's flat fee schedule: employers have as an incentive to underfund the plan and invest 
in risky assets. Recent legislation has increased an employer's liability for unfunded pension benefits. This action can be justified on the grounds that it will help reduce the moral hazard problems associated with the flat premium schedule. However, this article shows that an increase in an employer's liability can also reduce the incentive for firms that are close to default on pension obligations to invest in capital.

The PBGC insurance program also affects the cost of employing labor. If the pension benefits promised to labor are guaranteed by the PBGC, then an additional unit of labor increases the risk facing the PBGC. If the per employee insurance premium is not sufficient to compensate the PBGC for its additional risk, then the PBGC reduces the cost of labor. For significantly underfunded plans, the magnitude of this effect can be important.

The tax treatment of pension funds also affects the cost of employing labor. A corporate-sponsored pension plan enables employees to invest in taxable securities without paying tax on investment returns until they are distributed. In addition, shareholders can invest in the pension plan and earn the before-tax rate of return on taxable securities by contributing more to the plan than is needed to pay promised pension benefits (see Black, 1980, and Tepper, 1981). Since the IRS constraint on overfunding is loosened by hiring additional labor, an additional unit of labor enables shareholders to earn additional tax benefits.

The basic conclusion from the analysis is that the tax and insurance arrangements of the pension system tend to reduce the cost of labor relative to capital. This conclusion holds for both overfunded and underfunded pension plans. For overfunded plans, the tax treatment reduces the cost of labor. For underfunded plans, the insurance system subsidizes labor and claims part of the returns to capital. Consequently, these institutional arrangements alter capital intensity in the United States.

The article proceeds as follows. In section 2 , I provide a brief description of the institutional arrangements governing pension plans. In section 3, I present the model and discuss the analytical results. The article concludes with a summary.

\section{Description of the pension system}

This article deals exclusively with corporate-sponsored, defined-benefit pension plans. Under a defined-benefit plan, employees are promised a specific benefit when they retire. The promised benefit usually depends on the salary and the service of the employee. The employer makes periodic contributions to a fund, from which the pension benefits are paid. ${ }^{2}$

Several aspects of the tax code are important for defined-benefit plans. First, corporate contributions are tax deductible. Second, earnings on pension assets are not taxed, at the corporate or personal levels, as they are earned. Third, distributions from a pension fund are taxable when they are received. 
The preferential tax treatment allows employees to save at a tax-deferred rate. In addition, Black (1980) and Tepper (1981) show that the tax treatment allows corporations to earn the before-tax rate of return on taxable securities. To take advantage of this opportunity, corporate sponsors contribute more to the fund than is needed to pay promised benefits and subsequently remove excess contributions. ${ }^{3}$

Prior to 1974 , most pension benefits were not backed by the firm's assets. ${ }^{4}$ McGill (1974) reports that prior to 1974 only 13 percent of 225 surveyed firms backed some or all pension benefits with corporate assets. A firm that did not back benefits with corporate assets could terminate an underfunded plan and have no legal obligation to pay unfunded benefits. Thus, prior to 1974, an employer's liability for unfunded pension benefits was very limited. ${ }^{5}$

In 1974, Congress passed the Employee Retirement Income Security Act (ERISA). ERISA established a federal insurance agency, the Pension Benefit Guarantee Corporation (PBGC), to insure pension benefits. ERISA also made firms liable for unfunded pension liabilities up to 30 percent of their net worth. Thus, if an unfunded pension plan were terminated, the PBGC paid the difference between unfunded liabilities and 30 percent of the sponsor's net worth. ${ }^{6}$

In 1985, Congress passed the Single Employer Pension Plan Amendments Act (SEPPAA). SEPPAA changed the conditions under which a pension plan can be terminated. Prior to SEPPAA, a going concern could terminate an underfunded plan by paying the PBGC 30 percent of the firm's net worth. SEPPAA, however, eliminates the ability of a going concern to terminate an underfunded pension plan. ${ }^{7}$ SEPPAA also increased an employer's liability by giving the PBGC a secondary claim against the firm equal to 75 percent of the value of unfunded guaranteed vested benefits not covered by the PBGC's prior claim. ${ }^{8}$

In 1987, Congress restricted even further the ability of a firm to terminate an underfunded plan. The Pension Protection Act requires firms that wish to terminate an underfunded plan in a reorganization to demonstrate that the termination is necessary for the continued existence of the firm. ${ }^{9}$

Table 1 compares an employer's liability for unfunded pension benefits over different time periods. The conclusion from table 1 is clear: an employer's liability for unfunded pension benefits has increased over time.

The PBGC initially charged all firms a flat annual fee of $\$ 1$ per employee for the insurance. This fee was increased in 1978 to $\$ 2.60$, and again in 1986 to $\$ 8.50$. In 1988 , the fee increased to $\$ 16$ per employee plus an additional $\$ 6$ for every $\$ 1,000$ that the plan was underfunded per employee. However, the maximum fee is $\$ 50$ per employee.

\section{The model}

\subsection{Description}

A single period model is developed to examine the effects of the pension system on the operating decisions of the firm. In the model, the firm has two decision 
Table 1. Description of employers' liability for unfunded pension liabilities.

\begin{tabular}{|c|c|c|c|c|}
\hline & \multicolumn{2}{|c|}{ ERISA } & \multicolumn{2}{|c|}{ PPA } \\
\hline & Prior to 1974 & $1974-1985$ & 1986-1988 & $1988 \rightarrow ?$ \\
\hline \multicolumn{5}{|l|}{ Going concern } \\
\hline Able to terminate & Yes & Yes & No & No \\
\hline Employer liability & 0 & $\begin{array}{l}30 \% \text { of net } \\
\text { worth }\end{array}$ & $*$ & $*$ \\
\hline \multicolumn{5}{|l|}{ Reorganization } \\
\hline Able to terminate & Yes & Yes & Yes & $\begin{array}{l}\text { Only if } \\
\text { termination } \\
\text { is necessary } \\
\text { for continued } \\
\text { existence of } \\
\text { firm }\end{array}$ \\
\hline Employer liability & 0 & $\begin{array}{l}30 \% \text { of net } \\
\text { worth }\end{array}$ & $\begin{array}{l}30 \% \text { of } \\
\text { net worth } \\
+75 \% \text { of } \\
\text { unfunded } \\
\text { benefits. }\end{array}$ & $\begin{array}{l}30 \% \text { of net } \\
\text { worth }+75 \% \text { of } \\
\text { unfunded } \\
\text { liabilities. }\end{array}$ \\
\hline
\end{tabular}

* Not relevant because termination is not possible.

Notes: Assumptions-No employer guarantee.

ERISA-Employee Retirment Income Security Act of 1974.

SEPPAA-Single Employer Pension Plan Amendments Act of 1985.

PPA-Pension Protection Act of 1987.

variables: the amount of labor employed and the amount of capital employed. Two times are distinguished: the beginning of the period and the end. The decisions are made under uncertainty at the beginning of the period. At the end of the period, the random variables are revealed, and the payoffs to the firm's claimants are made. The notation for the model is summarized in table 2 .

\subsection{The beginning-of-period decisions}

At the beginning of the period, the firm contracts with its factors of production: labor and capital. Let $L$ denote the number of employees and $K$ the number of units of capital employed. Labor is compensated with a wage, $w$, paid at the beginning of the period, and with a promised pension benefit, $b$, to be paid at the end. Each unit of capital is compensated at the beginning of the period with a rental rate, $\rho .{ }^{10}$ The current wage, $w$, the pension benefit, $b$, and the rental rate for capital, $\rho$, are determined by the labor and capital markets, and are exogenous to the model. ${ }^{\prime \prime}$

Also at the beginning of the period, the firm contributes to a pension fund (the funding decision) and invests the money in securities (the asset allocation deci- 
Table 2. Notation.

$\mathrm{BOP}=$ the beginning of the period.

$\mathrm{EOP}=$ the end of the period.

$Q(K, L)=$ production function which is homogeneous of degree one.

$P=$ price of output (unknown at BOP, revealed at EOP).

$w=$ wage rate $($ known at $\mathrm{BOP})$.

$\rho=$ cost of capital (known at BOP).

$b=$ promised pension benefit per unit of labor (known at BOP).

$L=$ amount of labor employed (chosen at BOP).

$K=$ amount of capital employed (chosen at BOP).

$\beta=$ proportion of pension assets invested in the risky security (exogenous).

$I=$ investment by equityholders.

$C=c B=$ contribution to the pension fund.

$R=P^{*} Q(K, L)=$ income from operations.

$B=b L=$ pension liabilities at the end of the period.

$\tau=$ common tax rate on interest income $=$ corporate tax rate.

$r=$ equilibrium expected return on equity (known at BOP).

$r_{f}=$ before-tax equilibrium return on the risk-free security.

$\mu=r \beta+r_{f}(1-\beta)(1-\tau)=$ expected after-tax rate of return on pension assets for a taxable investor.

$\alpha=r \beta+r_{f}(1-\beta)=$ expected rate of return on pension assets for a nontaxable investor.

$r_{a}=$ after-tax expected rate of return on the firm's productive assets.

$A_{0}=C e^{\alpha-\mu}=$ BOP value of pension assets.

$\gamma=$ PBGC's claim on the net worth of the firm.

$A_{1}=$ EOP value of pension assets.

$Z=A_{0}+\gamma \bar{R}^{-r_{a}}$

sion). Let $B$ equal the total amount of promised pension benefits $(B=b L)$, and let $C$ represent the contribution to the pension fund. The contribution to the pension fund is modeled as a constant times the promised pension benefit:

$$
C=c B
$$

This assumption captures the dependence of the contribution on the total amount of promised pension benefits and therefore on the amount of labor employed. The parameter $c$ is exogenous in this model.

Consistent with the literature on the management of pension funds, I assume that there exist two securities in which the pension assets are invested: risk-free bonds and risky equity. The returns on equity are not taxed, whereas the returns on bonds are taxable to individual investors but not to the pension fund. The equilibrium expected return on equity is $r$, and the equilibrium before-tax return on bonds is $r_{f}$. Let $\tau$ represent the marginal tax rate for investors on interest income and also the corporate tax rate. ${ }^{12}$

The parameter, $\beta$, represents the proportion of pension assets invested in equity. ${ }^{13}$ Therefore, the expected rate of return on the pension assets is

$$
\alpha=\beta r+(1-\beta) r_{f} .
$$


This rate of return is greater than a taxable investor could expect to earn if he/she invested in the same portfolio. In particular, the expected rate of return to a taxable investor is

$$
\mu=\beta r+(1-\beta) r_{f}(1-\tau) .
$$

The value of the pension assets at the beginning of the period is denoted by $A_{0}$. Notice that a distinction is made between the contribution to the pension fund, $C$, and the beginning of period value of the pension assets, $A_{0}$. These values may differ because of the tax treatment of the pension plan. Consider the value of a $\$ 1$ contribution to the pension fund. The expected value of the dollar at the end of the period is $e^{\alpha}$, where $\alpha$ is the expected rate of return on pension assets. The appropriate discount rate for finding the present value of $e^{a}$ is $\mu$, the after-tax rate of return a taxable shareholder could expect to earn on the same assets. Thus, the difference:

$$
A_{0}-C=C\left(e^{\alpha-\mu}-1\right),
$$

represents the net present value of contributing $C$ dollars to the pension fund. If all of the pension assets are invested in equity $(\gamma=1)$, then $\alpha$ equals $\mu$, and therefore, $A_{0}$ equals $C$.

Summarizing, the decision variables are the choice of labor and capital $(L, K)$. The pension funding and asset allocation policies, represented by the parameters $c$ and $\beta$, respectively, are exogenous. The funds needed to pay the factors of production and to contribute to the pension fund are obtained from equityholders. Thus, the investment by equityholders at the beginning of the period is given by

$$
I=w L+c b L+\rho K+f(L) .
$$

The first term represents the current wages paid to employees. The second term is the contribution to the pension fund, and the third term represents the expenditure on capital. The last term, $f(L)$, is the insurance premium paid to the PBGC. Initially, $f(L)$ was equal to $L$. Under current $\mathrm{PBGC}$ rules,

$$
f(L)=\left[16+\operatorname{Max}\left(0, \operatorname{Min}\left(\frac{6\left(B e^{-r} f-A_{0}\right)}{1000 L}, 34\right)\right)\right] L .
$$

\subsection{The end-of-period payoffs}

Let $P$ be the price of output at the end of the period and $A_{1}$ be the end-of-period value of the pension assets. ${ }^{14}$ The revenue from production, $R$, is equal $P Q(K, L)$, where $Q(K, L)$ is a linearly homogeneous production function. ${ }^{15}$

The firm's liability for unfunded pension benefits is modeled by the parameter $\gamma$ 
which represents the proportion of the firm's net worth that backs pension benefits. Over the 1974-1985 period, $\gamma$ equaled 0.3. Since 1985, Congress has not only explicitly increased $\gamma$ but it has also implicitly increased $\gamma$ by restricting the ability of a firm to terminate an underfunded pian. Presently, $\gamma$ is close to unity, that is, pension benefits are fully backed by corporate assets. If the end-of-period value of the pension assets plus $\gamma$ percent of the revenue from operations is greater than the promised pension benefits (i.e., if $A_{1}+\gamma R \geqslant B$ ), then the firm pays all of the pension benefits and distributes the remaining pension assets and income from operations to the firm's shareholders.

If the end-of-period value of the pension assets plus $\gamma$ percent of the income from operations is less than the promised pension benefit (i.e., if $A_{1}+\gamma R<B$ ), then the firm defaults on its pension obligations. In this case, the PBGC claims the pension assets and assumes the pension liability. In addition, the PBGC claims $\gamma$ percent of the firm's net worth which is equal to $\gamma$ percent of the income from operations. The employees receive their promised pension benefits from the PBGC. Table 3 summarizes the payoffs.

The end-of-period payoff to equityholders is

$$
R+A_{1}-B+\operatorname{Max}\left(B-A_{1}-\gamma R, 0\right) \text {. }
$$

The beginning-of-period value of this cash flow is

$$
\bar{R} e^{-r_{a}}+A_{0}-B e^{-r_{f}(l-\tau)}+\operatorname{Put}(Z, B, \sigma),
$$

where

Table 3. EOP payoffs.

\begin{tabular}{llll} 
States & $\begin{array}{l}\text { Payoff to } \\
\text { Equityholders }\end{array}$ & $\begin{array}{l}\text { Payoff to } \\
\text { Beneficiaries }\end{array}$ & $\begin{array}{l}\text { Payoff to } \\
\text { PBGC }\end{array}$ \\
\hline $\begin{array}{l}A_{1} \geqslant B \\
A_{1}<B\end{array} \quad \& \quad$ & $R+A_{1}-B$ & $B$ & 0 \\
$\begin{array}{l}\gamma R+A_{1} \geqslant B \\
A_{1}<B\end{array}$ & $R+A_{1}-B$ & $B$ & 0 \\
$\begin{array}{l}\gamma R \\
\text { Summary }\end{array}$ & $(1-\gamma) R$ & & $A_{1}+\gamma R-B$ \\
\hline
\end{tabular}

${ }^{*} \operatorname{Max}\left[R+A_{1}-B,(1-\gamma) R\right]=R+A_{1}-B+\operatorname{Max}\left[B-A_{1}-\gamma R, 0\right]$

Definitions:

$A_{1}=$ end-of-period value of the pension assets.

$B=$ end-of-period value of the pension liability (known at the beginning of period).

$R=$ end-of-period value of the net worth of the firm.

$\gamma=$ percent of net worth that the employer is liable for. 


$$
\begin{aligned}
& Z=A_{0}+\gamma \bar{R} e^{-r_{a}} \\
& A_{0}=\text { beginning-of-period value of the pension assets, }
\end{aligned}
$$

and the bar over a variable indicates the expected value. The discount rate, $r_{a}$, is the equilibrium after-tax discount rate for the firm's expected revenue from production. The final term represents the value of a European put option with the initial value of the underlying asset being $Z$ and with an exercise price $B$. The standard deviation of the rate of return on the underlying asset is denoted by $\sigma$. The standard Black-Scholes model is used to value the pension put option. ${ }^{16}$

\subsection{The firm's problem}

The before-corporate-tax value of the firm is equal to the beginning of period value of the cash flows less the expenditures on inputs:

$$
\begin{aligned}
V= & \bar{P}^{*} Q(K, L) e^{-r_{a}}-w L-\rho K+A_{0}-C-B e^{-r_{f}^{(1-\tau)}} \\
& +\operatorname{Put}[Z, B, \sigma]-f(L) .
\end{aligned}
$$

The firm maximizes $V$ by choosing $L$ and $K$. The first three terms represent the value of a firm without a defined benefit pension plan, and the next five terms are due to the pension plan.

The first-order conditions are as follows: $:^{17}$

$$
\begin{aligned}
K: \bar{P} Q_{K} e^{-r_{a}}= & \rho-\frac{\partial \text { Put }}{\partial Z} \frac{\partial Z}{\partial K} . \\
L: \bar{P} Q_{L} e^{-r_{a}}= & f_{L}+w+b c-b\left[c e^{\alpha-\mu}-e^{-r_{f}(1-\tau)}\right] \\
& -\frac{\partial \text { Put }}{\partial Z} \frac{\partial Z}{\partial L}-\frac{\partial \text { Put }}{\partial B} b .
\end{aligned}
$$

Equation (1) implies that capital is employed until the value of the marginal product of capital equals the cost of capital:

$$
\bar{P} Q_{K} e^{-r_{\alpha}}=\frac{\rho}{1-\gamma[1-N(h)]} .
$$

The term $[1-N(h)]$ can be thought of as the probability that the firm will default on its pension obligations. ${ }^{18}$ This interpretation implies that the second term in the denominator of equation ( $\left(1^{\prime}\right)$ equals the expected claim of the PBGC on the value 
of the marginal product of capital. Thus, the cost of the capital is the rental fee for capital "grossed up" by one minus the expected claim of the PBGC.

The intuition underlying this result is as follows. An increase in the use of capital increases the expected cash flows from production. Since the PBGC has a contingent claim on $\gamma$ percent of the firm's cash flows, not all of the increase in the value of expected cash flows accrues to shareholders. The second term in the denominator of expression $\left(\mathrm{I}^{\prime}\right)$ represents the portion of the value of the marginal product of capital that accrues to the PBGC. The problem is that the PBGC's insurance policy is not priced properly. If the insurance were priced actuarially fair, then any reduction in the PBGC's risk due to higher expected cash flows would accrue to the firm through a reduction in the insurance premium.

The magnitude of the effect of the PBGC insurance on the marginal cost of capital depends on a firm's financial condition. Suppose the pension plan is considerably overfunded. In this case, the effect of the PBGC insurance is small because it is unlikely that the firm will default on its pension obligations (i.e., $[N(h)$ $\approx 1$ ). Suppose, on the other hand, that the pension fund is so underfunded that the firm is likely to default on its pension obligations (i.e., $N(h) \approx 0$ ). In this case, the effect of the PBGC insurance is large: $\gamma$ percent of any increase in expected cash flows will accrue to the PBGC, not to the shareholders. If, for example, $\rho=.12$ and $\gamma=.3$ and the firm is almost certain to default on pension liabilities, then the required return to capital is approximately 17 percent. Under the same assumptions, but with $\gamma=.5$, the cost of capital is 24 percent. Thus, the cost of capital can be significantly greater than the rental rate if the likelihood of default on pension obligations is high.

The effect of increasing a firm's liability for unfunded pension benefits on the cost of capital is found by examining how an increase in $\gamma$ affects the right-hand side of equation $\left(1^{\prime}\right)$. The parameter $\gamma$ appears explicitly in the denominator of $\left(1^{\prime}\right)$. In addition, the term $[1-N(h)]$, representing the probability that the firm will default on its pension obligations, is a decreasing function of $\gamma$. The product of $[1-N(h)]$ and $\gamma$ represents the expected proportion of the value of the marginal product of capital that does not accrue to shareholders. An incresae in $\gamma$ decreases the likelihood that the firm will default on its pension obligations (i.e., $[1-N(h)]$ decreases). On the other hand, an increase in $\gamma$ increases the firm's liability if it defaults on pension obligations occurs. Thus, there are two effects of increasing $\gamma$ on the cost of capital in this model. ${ }^{19}$ The dominating effect depends on the financial condition of the firm. If the firm is very likely to default on its pension obligations, then a marginal increase in the firm's liability will increase the cost of capital. Intuitively, an increase in the firm's liability reduces the portion of the cash flows from capital that accrue to shareholders. On the other hand, if the firm is extremely unlikely to default on pension obligations, an increase in $\gamma$ has very little effect on the cost of capital. ${ }^{20}$

The result that the PBGC's insurance contract increases the cost of capital is analogous to the result found in Myers (1977) that a firm's investment decision is affected by the presence of risky debt. In Myers' paper, debtholders have a fixed 
claim against the firm's assets, and this claim is negotiated prior to the firm's investment decision. If a portion of the returns from a new investment project accrue to debtholders, then the incentive for equityholders to invest is reduced. Note, however, that debtholders and equityholders have an incentive to mitigate this problem through firm specific contractual arrangements and through renegotiation. (See Myers, 1977, for a discussion.)

In this article, the PBGC has a contingent claim to a percentage of the firm's assets. This claim has been set by Congress prior to many firms' investment decisions. In states of the world in which pension assets are low relative to pension liabilities, a portion of the returns on new investments accrue to the PBGC. Consequently, the incentive for equityholders to invest is reduced. Unlike the case of debt, specialized arrangements for dealing with this problem are not available under current PBGC rules.

The first-order condition for the choice of labor can be written as equation $\left(2^{\prime}\right)$ :

$$
\begin{aligned}
\bar{P} Q_{L} e^{-r_{a}}= & w+b e^{-r_{f}(1-\tau)}-b c\left[e^{a-\mu}-1\right]+f_{L} \\
& -\frac{\partial \text { Put }}{\partial Z}\left[b c e^{a-\mu}+\gamma \bar{P} Q_{L} e^{-r_{a}}\right]+\frac{\partial \mathrm{Put}}{\partial B} b .
\end{aligned}
$$

The LHS of equation ( $\left.2^{\prime}\right)$ equals the value of the marginal product of labor, and the RHS equals the marginal cost of labor. The firm employs labor until the value of its marginal product equals its marginal cost. The first two elements of the marginal cost are the current wage and the present value of the pension benefits. The third term represents the marginal tax benefits from the pension fund as an additional unit of labor is employed. The fourth term equals the additional insurance premium for each unit of labor. The final terms represent the change in the value of the put option as an additional unit of labor is employed.

In the absence of the tax treatment and the benefit insurance of defined-benefit plans, the marginal cost of labor would simply equal the current wage, $w$, plus the present value of the promised pension benefit discounted at the after-tax risk free rate, $b e^{-r_{f}(1-\tau)}$. The institutional arrangements of the pension system, however, significantly alter the marginal cost of labor. Each of these factors is discussed subsequently.

The marginal tax benefits from the pension fund are

$$
b c\left(e^{\alpha-\mu}-1\right) \geqslant 0 .
$$

The term in parentheses is the net present value of each dollar contributed to the pension fund; it depends on the pension asset allocation decision. The term, $b c$, is the contribution to the pension fund for each unit of labor; it depends on the pension funding decision. If the firm invests all of the pension assets in equity, then $\alpha=\mu$ and the tax benefits are zero. If the firm contributes as much as possible to 
its pension fund $\left(c=c_{\max }\right)$ and invests all of the pension assets in bonds, then the marginal tax benefits are maximized. ${ }^{21}$

Let $c^{*}$ equal the value of the funding variable that would make the pension assets equal to the pension liabilities, and suppose $c=c_{\max }$. Then, the marginal tax benefits can be written as

$$
b c_{\max }\left(e^{\alpha-\mu}-1\right)=b c^{*}\left(e^{\alpha-\mu}-1\right)+b\left(c_{\max }-c^{*}\right)\left(e^{\alpha-\mu}-1\right) .
$$

The marginal tax benefit is comprised of two terms. The first term represents the marginal tax benefits if the firm contributed just enough to the pension fund to pay off its pension obligations. These tax benefits arise because the pension fund does not pay taxes on investment earnings, whereas employees do. As a result, the pension fund can earn a higher rate of return than employees. This analysis implicitly assumes that employees do not have alternative tax-deferred investment opportunities, such as IRAs. The existence of unlimited tax deferred investment opportunities would imply that the first term may not be part of the pension tax benefits. See Mumy (1985) for a thorough analysis of this issue.

The second term represents the additional tax benefits if the firm contributes more to the pension fund than is needed to pay its pension obligations. These additional tax benefits arise because the pension fund can earn the before-tax rate of return, whereas shareholders can only earn the after-tax rate of return on taxable securities. If shareholders have unlimited tax deferred investment opportunities, then the second term in expression (3) would not be part of the tax benefits. Empirical evidence indicates that there is a premium paid for tax-exempt securities which implies that unlimied tax-deferred investment opportunities are not available to the marginal investor. ${ }^{22}$

The marginal effect of a unit of labor on the value of the PBGC insurance is complicated, because an additional unit of labor changes the value of pension liabilities and also the value of assets backing pension liabilities. The pension liability increases as an additional unit of labor is employed because the total amount of promised benefits increases. The assets backing pension liabilities increase for two reasons: (1) the firm must contribute more to the pension fund, and (2) the cash flows of the firm backing pension liabilities increase by $\gamma$ percent of the value of the marginal product of labor. Thus, there are offsetting effects of an additional unit of labor on the value of the PBGC insurance. The following proposition, however, shows that one effect always dominates.

$$
\text { Proposition: } \frac{\partial \text { Put }}{\partial L} \text { is positive. }
$$

Proof: See Appendix.

The proposition states that, independent of the funding and asset allocation 
decisions, the marginal effect of an additional unit of labor on the put option is positive.

Thus, a benefit of employing labor is that it increases the value of the firm's right to default on pension obligations. However, the firm must pay an additional $f_{L}$ dollars to the PBGC for the insurance. If $\partial \mathrm{Put} / \partial L$ is greater than $f_{L}$, then the PBGC insurance reduces the cost of labor. On the other hand, if $f_{L}$ is greater than $\partial \mathrm{Put} / \partial L$, then the PBGC insurance increases the cost of labor.

In summary, the tax treatment and the insurance aspects of defined benefit plans reduce the marginal cost of labor by the amount

$$
S=b c\left[e^{a-\mu}-1\right]+\frac{\partial \text { Put }}{\partial L}-f_{L} .
$$

The magnitude of the subsidy depends on the funding and asset allocation policies of the firm. For example, if all the pension assets are invested in equity, then the tax benefits are zero. On the other hand, if all the pension assets are invested in debt and the firm contributes as much as possible to the pension fund, then the tax benefits are maximized. Finally, the marginal value of the put option is likely to be greater than the insurance premium when the plan is significantly underfunded.

\section{Summary and Conclusion}

This article extends previous research on the management of corporate pension funds by examining the impact of the pension system on the operating decisions of the firm. Both the PBGC insurance arrangements and the tax treatment of defined benefit pension plans alter the relative costs of labor and capital. The PBGC insurance increases the cost of capital. In addition, the PBGC insurance causes the marginal cost of labor to be less than the value of the contractual compensation if the marginal value of the insurance is greater than the flat fee charged by the PBGC. Also, the corporate tax treatment of defined benefit pension plans lowers the cost of labor by providing a tax deferred investment opportunity for both employees and shareholders.

The distortions induced by the tax and insurance arrangements depend on the financial pension policies of the firm. For example, the more underfunded the pension plan is, the greater is the cost of capital. The greater the proportion of assets invested in bonds, the greater the tax subsidy to labor.

The analysis also illustrates an effect of the recent trend toward increasing a firm's liability for unfunded pension liabilities. By forcing firms to back pension benefits with corporate assets, the Congress has created a fixed claim to corporate assets that competes with equityholders' claims. A firm's liability for unfunded pension liabilities reduces shareholders' incentives to invest in capital because 
part of the returns to these investments are shared with the PBGC. Thus, increasing a firm's liability for unfunded pension benefits (without adjusting the premium schedule) increases the cost of capital.

\section{Notes}

1. Endogenizing the financial pension policies in this model does not provide new insights about these decisions; therefore, they are treated as exogenous to simplify the exposition.

2 . The other major type of pension plan is a defined-contribution plan. Under a defined-contribution plan, a set amount of money is contributed to a fund each period and the retiree receives the total contributions and the earnings on the contributions. TIAA-CREF is an example of a definedcontribution plan. Although more defined contribution plans exist in the United States than definedbenefit plans, approximately 75 percent of all pension plan participants are enrolled in definedbenefit plans.

3. A firm can remove excess pension assets in one of two ways. First, the firm can terminate the overfunded plan and establish another plan that is less overfunded. A less visible way is to change the actuarial assumptions and implicitly remove assets by contributing less to the fund.

4. For a more thorough analysis of an employer's liability for unfunded pension benefits, see Soble and associates (1982).

5. Employees presumably understood the limited liability of employers with respect to pension claims, and consequently required higher (lower) compensation (in terms of higher wages) when the risk of not receiving their promised benefits increased (decreased).

6. Actually, the PBGC has a ceiling on the benefits that are guaranteed. In addition, the guarantee of benefits arising from plan amendments are phased in over a five-year period.

7. SEPPAA allows an underfunded pension plan termination (i.e., a distress termination) only if the employer satisfies one of the following conditions: (1) filed a petition seeking liquidation; (2) filed a petition seeking reorganization; (3) convinces the PBGC that the firm will be unable to pay its debts and unable to continue in business if a termination is not granted; or (4) convinces the PBGC that the "costs of providing pension coverage has become unreasonably burdensome as a result of a declining work force." For further discussion, see chapter 22, "Plan Termination," in Employee Benefits Handbook edited by Jeffrey D. Mamorsky (1987).

8. The PBGC's secondary claim can be paid in installments over a number of years, and any yearly installment can be partially deferred if the firm does not have profits in that year. In addition, SEPPAA created a liability for pension commitments exceeding guaranteed benefits.

9. The Pension Protection Act also increased a firm's liability for benefits exceeding guaranteed benefits.

10. By paying wages at the beginning of the period and pension benefits at the end of the period, the model captures the deferred compensation aspects of actual pension plans. Also, by having wages and the rental fee for capital paid at the beginning of the period, these payments are not made contingent on the performance of the firm. This assumption eliminates potential incentive problems associated with labor and capital, and focuses the analysis on the incentive problems between equityholders and the PBGC.

11. By taking the mix between wages and pension compensation as given, the analysis ignores the effect of government pension policy on the terms of labor contracts. For an analysis of how ERISA altered the desirability of pension compensation, see Niehaus (1988). Also by taking the required compensation for labor and capital as given, the analysis ignores general equilibrium effects of government pension policy on the equilibrium costs of labor and capital.

12. These assumptions are sufficient to obtain a Miller equilibrium, although they are not necessary. 
13. The portfolio is continuously rebalanced so that $\beta$ is the proportion of pension assets invested in equity at all points in time. Also, taxes are paid continuously throughout the period.

14. The price of output is assumed to follow a continuous process through time. This assumption is needed to use standard option pricing models later in the article. Production is assumed to take place at the end of the period, so the expected price at the end of the period is the relevant parameter for decisionmaking.

15. The assumption of a linearly homogeneous production function is used to prove a proposition later in the article.

16. In order for the put option to be valued in a manner consistent with the Black-Scholes methodology, the value of the sum of income from operations and pension assets must follow a Brownian motion process. More precisely, if $Z_{t}=\gamma R_{t}+A_{t}$, then $d Z / Z=\pi d_{t}+\sigma d W$, where $W$ is a standard Brownian motion process. In this case, the value of the put is:

$$
\text { Put }[Z, B, \sigma]=Z[N(h)-1]+B e^{-r} f N(\sigma-h),
$$

where

$$
\begin{aligned}
& Z=\left(Y+A_{0}\right), \\
& Y=\gamma \bar{P}^{*} Q(K, L) e^{-r_{a}} \\
& h=\frac{1}{\sigma}\left[\log \left(\frac{Z}{B}\right)+r_{f}\right]+\frac{\sigma}{2},
\end{aligned}
$$

$N($ ) = the cumulative standard normal distribution function.

$Y$ represents the value of the corporate (nonpension) assets backing the pension liabilities.

17. The second-order conditions are assumed to be satisfied.

18. Technically, this interpretation is correct only if the assets backing the pension liabilities grow at the instantaneous rate of $\left(r_{f}+\sigma^{2}\right)$, where $\sigma$ is the instantaneous standard deviation of the underlying asset.

19. Another effect of increasing the firm's liability (not modeled here) is a reduction in moral hazard problems such as underfunding and investing in risky assets.

20. These statements can be shown more rigorously by differentiating the right-hand side of equation (1') with respect to $\gamma$ and considering limiting cases.

21. ERISA imposed minimum contribution rates for defined-benefit plans. In reality, there is no limit on the maximum contribution to a defined-benefit plan. However, there is an IRS limit on the amount of pension contributions that receive preferential tax treatment. The parameter, $c_{\max }$, is intended to capture the IRS constraint.

22. See, for example, Trzcinka (1982).

\section{References}

Bicksler, J., and Chen, A. "The Integration of Insurance and Taxes in Corporate Pension Strategy." Journal of Finance 40 (July 1985).

Black, Fischer. "The Tax Consequences of Long-Run Pension Policy." Financial Analysts Journal 36 (July-August 1980), 25-31.

Bodie, Z., and Light, J., Morck, R., and Taggart, R. "Funding and Asset Allocation in Corporate Pension Plans: An Empirical Investigation." In: Z. Bodie, J. Shoven, and D. Wise, eds., Issues in Pension Economics. Chicago: University of Chicago Press, 1987. 
Friedman, B. "Pension Funding, Pension Asset Allocation, and Corporate Finance: Evidence from Individual Company Data." In: Z. Bodie and J. Shoven, eds., Financial Aspects of the United States Pension System. Chicago: University of Chicago Press, 1983.

Harrison, J. M., and Sharpe, W. "Optimal Funding and Asset Allocation Rules for Defined Benefit Pension Plans." In: Z. Bodie and J. Shoven, eds., Financial Aspects of the United States Pension System. Chicago: University of Chicago Press, 1983.

Langetieg, T. "Optimal Funding and Investment Policy For Defined Benefit Pension Plans." Working Paper, University of Southern California, September 1983.

Light, J., and Perold, A. "Risk-Sharing and Corporate Pension Policies." Working Paper, Harvard Business School, 1985.

Mamorsky, J., ed., Employee Benefits Handbook 1987 Update. Boston: Warren, Gorham, and Lamont, 1987.

Marcus, A. "Corporate Pension Policy and the Value of PBGC Insurance." In: Z. Bodie, J. Shoven, and D. Wise, eds., Issues in Pension Economics. Chicago: University of Chicago Press, 1987.

Miller, Merton. "Debt and Taxes." Joumal of Finance 32 (May 1977).

Mumy, Gene E. "The Role of Taxes and Social Security in Determining the Structure of Wages and Pensions." Journal of Political Economy 93, No. 3 (1985).

Myers, S. "Determinants of Corporate Borrowing." Journal of Financial Economics (November 1977), $147-176$.

Niehaus, G. "The PBGC's Flat Fee Schedule, Moral Hazard and Promised Pension Benefits." Working Paper, The University of Michigan, 1988.

Sharpe, William F. "Corporate Pension Funding Policy." Journal of Financial Economics 3 (June 1976).

Soble, R., Eggertsen, J., and Bernstein, S. "Pension Related Claims in Bankruptcy." American Bankruptcy Law Journal 56 (1982), 155-179.

Tepper. Irwin. "Optimal Financial Strategies For Trusted Pension Plans." Joumal of Financial and Quantitative Analysis (June 1974).

Tepper, Irwin. "Taxation and Corporate Pension Policy." Journal of Finance 36 (March 1981).

Trzcinka, C. "The Pricing of Tax-Exempt Bonds and the Miller Hypothesis." Journal of Finance (September 1982).

Westerfield, R., and Marshall, W. "Pension Plan Funding Decisions and Corporate Shareholder Value: A New Model and Some Empirical Results." Unpublished Paper, University of Pennsylvania, September 1983.

Wise, D. A., ed. Pensions, Labor, and Individual Choice. Chicago: University of Chicago Press (for NBER), 1985. 
Appendix. Proof of proposition.

$$
\frac{\partial \mathrm{Put}}{\partial L}=[N(h)-1]\left[b c e^{\alpha-\mu}+\frac{\partial Y}{\partial L}\right]+e^{-r_{f} N(\sigma-h) b .}
$$

Multiplying by $L / L$ yields

$$
\frac{\partial \mathrm{Put}}{\partial L}=\frac{1}{L}[N(h)-1]\left[A_{0}+L \frac{\partial Y}{\partial L}\right]+B e^{-r_{f N}(\sigma-h) .}
$$

The homogeneity of the production function implies

$$
L \frac{\partial Y}{\partial L}=Y-\frac{\partial Y}{\partial K} K
$$

Substituting yields

$$
\frac{\partial \mathrm{Put}}{\partial L}=\frac{1}{L}\left\{[N(h)-1]\left[\left(A_{0}+Y\right)-\frac{\partial Y}{\partial K} K\right]+B e^{-r} f N(\sigma-h)\right\} .
$$

Combining terms yields

$$
\frac{\partial \mathrm{Put}}{\partial L}=\frac{1}{L}\left\{\mathrm{Put}-[N(h)-1] \frac{\partial Y}{\partial K} K\right\} \geqslant 0 .
$$

